\title{
Cytitoxic Activity from the Tuber of Cassava (ManihotesculentaCrantz) Against Servical Hela Cancer Lines
}

\author{
Diana Widiastuti, Supriatno Salam, Desi Haneti, Ronny Lesmanaand Unang Supratman
}

\begin{abstract}
This research evaluated the cytotoxic effect of the extract of cassava (M. Esculentacrantzs) againtsservicalHela cancer line. The tuber of Cassava is first extracted with ethanol at room temperature. The ethanol extract was dissolved in water and the partitioned successively with n-hexane and n-butanol. All of the extract were evaluated their cytototoxic activity againstservicalHela cancer line in vitro using MTT methods. The results indicate that the n-butanol showed strongerst cytotoxic activity with IC50 value of $1.07 \mathrm{ug} / \mathrm{mL}$.
\end{abstract}

Index Terms: Cytotoxic activity,Cervical Hela cancer cells, Cassava Sao Pedro Petro,ManihotesculentaCrantz

\section{INTRODUCTION}

Cassava is a family Euphorbiaceae, cultivar mainly for its starchy roots. It is one the most important food staples in the tropics country [1]. Its South America (Brazil), where is originated [2] and was introduced to most parts of Asia in the later $18^{\text {th }}$ and early $19^{\text {th }}$ centuries. Some of location for the early arrival of cassava were in India, Java and Philippines [3].

Cassava extract has been used to control one form of cancer or the other in the Chinese traditional medicine [4] without scientific validation. Similarly, research based on both aqueous and methanol crude cassava extracts showed potential of anticancer activity [5].

Widiastuti, 2018 [6] used three cultivar of cassava samples from West Java Indonesia Adira-2, Karikil and Sao Pedro Petro. Cassava was first extracted with ethanol at room temperature, which was then partitioned succesively with n-hexane, ethyl acetate and n-butanol. All of the extracts were evaluated against P-388 murine leukemia cells in-vitro using MTT assay. As a result, the n-hexane extract of San Pedro Petro cassava from CisaruaBogor has an inhibition concentration $\left(\mathrm{IC}_{50}\right)$ value of $15.8 \mu \mathrm{g} / \mathrm{mL}$ which can prevent the growth of murine leukemia P-388 cancer cells.

According to Suprapti [7] Characteristics of Sao Pedro Petro cassava (Manihotesculentacrantzs) for leaves: leaf

Revised Manuscript Received on April 25, 2019.

Diana Widiastuti, Department of Chemistry, Faculty of Mathematics and Natural Science, Pakuan University, Indonesia. And Department of Chemistry, Faculty of Mathematics and Natural Sciences,

UniversitasPadjadjaran, Indonesia

Supriantno Salam, Department of Chemistry, Faculty of Mathematics and Natural Sciences, UniversitasPadjadjaran, Indonesia

Desi Hanaeti, Department of Chemistry, Faculty of Mathematics and Natural Sciences, UniversitasPadjadjaran, Indonesia

Ronny Lesmana, Department of Chemistry, Faculty of Mathematics and Natural Sciences, UniversitasPadjadjaran, Indonesia

UnangSupriatman, Department of Chemistry, Faculty of Mathematics and Natural Sciences, UniversitasPadjadjaran, Indonesia shoots are not hairy, light brown, finned 7-9 strands, long and narrow, pointed ends. Comparison of the width and length of fins 1: 6 , the base of the petiole is red, the middle part is yellowish green, and the end is red. For stems: The stem size is rather large, tall and slightly branched, Young stems are light green, old stems are grayish brown, and deep skin is dark green. For Tuber: Big, not contradictory, and interact with each other, bitter taste.
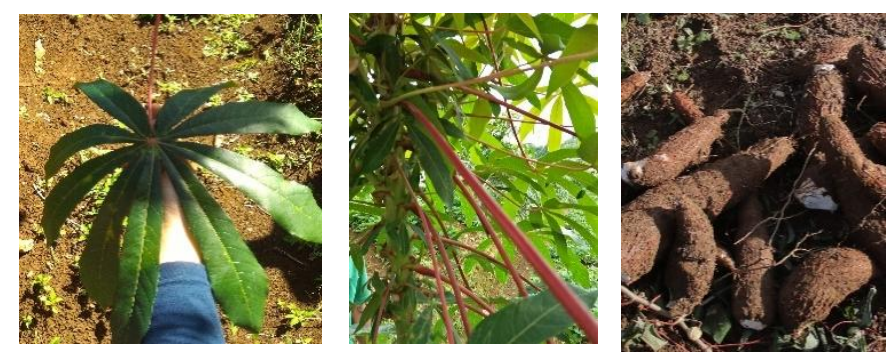

Picture 1. Leaf, stem and Tuber Cassava Sao Pedro Petro variety

Cancer burdens rises to 18.1 million new cases and 9.6 million cancer deaths in 2018 with estimated 570, 000 uterine cervical cancer cases [8]. Several factors could explain the recent increase in cervical cancer in pre-menopausal women in Japan, including low levels of screening uptake, changes in sexual behavior leading to increased prevalence of human papillomavirus (HPV) infection, and suspension of active recommendation of HPV vaccination in June 2013, [9]. Smoking increases the risk of cervical cancer among HPV positive women [10]

The extraction is performed with an ethanol solvent then partitioned successively, n-hexane and N-butanol. The cytotoxic test uses the method of Alley [11].

\section{MATERIALS AND METHODS}

\section{A. Plant Material.}

The Cassava (ManihotesculentaCrantz) were planted in KecamatanCisaruaKabupaten Bogor, West Java Province, Indonesia in April 2018. The plant was identified by the staff of the Bogoriense Herbarium, Bogor, Indonesia.

\section{B. Plant Extraction.}

Fresh cassava root cortex $(5 \mathrm{Kg})$ of Cassava (ManihotesculentaCrantz) was extracted with EtOH exhaustively (49 L) at room temperature for 7 days. After removal of the solvent under vacuum, the viscous concentrate of EtOH extract (340.01 g) was first suspended in $\mathrm{H}_{2} \mathrm{O}$ and then partitioned with n-hexane and n-butanol, successively. Evaporation resulted in the crude extracts of n-hexane (10.90 g) and $\mathrm{n}-\mathrm{BuOH}(228.63 \mathrm{~g})$, respecti 


\section{Determination of $\mathrm{IC}_{50}$ Value of Hela Cancer Cells}

The cytotoxic test of cancer by MTT method (3(4,5-dimethylazol-2-yl) -2,5-diphenyltetrazolium bromide) is done as follows: cancer cells with a concentration of $3 \mathrm{x}$ $103 \mathrm{sel} / 100 \mu \mathrm{L}$ are distributed into wells and incubated for 24 hours in a $\mathrm{CO} 2$ incubator so that the cells can adapt and stick to the wells. Then, a $100 \mu \mathrm{L}$ culture medium containing ethanol extract sample (vial I) is added to each well and they are incubated again for 48 hours. At the end of the incubation, the culture medium containing ethanol extract sample (vial I) is discarded and washed with $100 \mu \mathrm{L}$ PBS (Phosphate Buffered Saline). Next, into each well $100 \mu \mathrm{L}$ culture medium containing MTT is added and incubated for 4 hours at $37^{\circ} \mathrm{C}$. Living cells will react to MTT and form purple formazans. After 4 hours, a stopper reagent is added to each well to kill the cells and dissolve the formazan crystals. The plate is shaken with a shaker for 10 minutes then incubated at room temperature in a dark room overnight. Next, the absorbance of each well can be determined with an ELISA reader at a wavelength of $595 \mathrm{~nm}$. This process is carried out on the samples with ethanolic, n-hexane, n-butanol and water extracts.

\section{RESULT}

The cytotoxic test of HelaServical cancer cells using $\mathrm{IC}_{50}$ parameters is performed to reinforce the alleged activity of bioactive compounds from cassava tubers. The inhibition percentage of free radical absorption is the ability of a material to inhibit free radicals associated with the concentration of the material under test, whereas $\mathrm{IC}_{50}$ is a parameter frequently used in expressing the results of the test. $\mathrm{IC}_{50}$ value can be defined as the amount of concentration that can inhibit free radical activity that is as much as $50 \%$. The smaller $\mathrm{IC}_{50}$ value indicates the greater antioxidant activity in the tested material.

Table 1: Cytotoxic test of HelaServical cancer cells $\mathrm{IC}_{50}$

\begin{tabular}{ll}
\hline Extract & $\mathbf{I C}_{\mathbf{5 0}}(\boldsymbol{\mu g} / \mathbf{m L})$ \\
\hline Etanol & 6.651216 \\
n-Hexane & 4.723921 \\
n-Butanol & 1.073016 \\
Water & 9.498495 \\
\hline
\end{tabular}

The inhibition percentage of each extract obtained shows that the n-Butanol fraction gives the greatest inhibition characterized by the smallest $\mathrm{IC}_{50}$ among all fractions, that is $1.073 \mu \mathrm{g} / \mathrm{mL}$, followed by the $4.72 \mu \mathrm{g} / \mathrm{mL} \mathrm{n}$-hexane fraction, $6.652 \mu \mathrm{g} / \mathrm{mL}$ ethanol fraction and $9.498 \mu \mathrm{g} / \mathrm{mLwater}$ fraction. The cytotoxicity test using HelaServical cancer cells indicates that the extract of M. EsculentaCrantz, Sao Pedro Petro variety - cassava, in n-butanol and n-hexane fractions has very active inhibition power, thus, it has the potential to become anticancer.

\section{CONCLUSION}

The results indicate that the n-butanol extract of Sao Pedro Petro cassava (M. Esculenta crantzs) showed strongerst cytotoxic activity againts CervicalHela cancer cell line with IC50 value of $1.07 \mathrm{ug} / \mathrm{mL}$.

\section{ACKNOWLEDGMENT}

This research was financially supported by Directorate of Research and Community Service from Ministry if Research and Higher Education Republic of Indonesia. We acknowledge dr. BoediSadjarwa, S.P, Melvy, Sakinahand Vera for their help in sampling and analysis.

\section{REFERENCES}

1. Alfredo A. C.Alves, Cassava Botany and Physiology, $C A B$ International Cassava: Biology, Production and Utilization, chapter 5. Pp. 67-89, 2002

2. Claude Fauquet and Denis Fargette. African Cassava Mosaic Virus Etiology, Epidemiology, and Control. Plant Disease., 74(6), pp 404-11, 1990

3. I.C. Onwuene, , Cassava in Asia and the PasificCAB International Cassava: Biology, Production and Utilization, chapter 4, 55-65, 2002

4. Hock-HinYeoh, T. Tatsuma and N. Oyama, Monitoring the cyanogenic potential of cassava: the trend towards biosensor development, Thrends in Analytical Chemistry, vol 17:2, 234-239, 1998

5. Iyuke SE, Yusuf UF, Razil R, Fakhuru AI, Billa N, Achike FI Antitumoral action of linamarin and cassava tissue extracts. In: Proceedings of engineering for life. The 7th World Congress Chemical Engineering, vol 140, Scotland, pp 2-15, 2004

6. D.Widiastuti, A.H. Mulyati, E. Herlina, S. Warnasih, Triastinurmiatiningsing and U. Supratman, Cytotoxic Effects of Cassava (ManihotesculetaCrantz), Adira-2, Karikil and Sao Pedro Petro Varieties against P-388 Murine Leukemia Cells. Res. J. of Chemistry and Environment., 22, pp. 206- 208, 2018

7. Suprapti, Suprapti, L. Processing Technology of Tapioca Flour Food and its Utilization, GramediaPustaka pp.80, 2005

8. International Agency for Research on Cancer GLOBOCAN2018. from: http://gco.iarc.fr/today/fact-sheets-cancers.

9. Onuki M, Matsumoto K, Satoh $\mathrm{T}$, et al. Human papillomavirus infections among Japanese women: age-related prevalence and type-specifi risk for cervical cancer. Cancer Sci 2009;100:1312-6.

10. Plummer M, Herrero R, Franceschi S, et al. Smoking and cervical cancer: pooled analysis of the IARC multi-centric case-control study. Cancer Causes Control 14:805-814,2003;

11. Alley M.C., Scudiero D.A., Monks A., Hursey M.L., Czerwinski M.J., Fine D.L., Abbott B.J., Mayo J.G., Shoemaker R.H. and Boyd M.R., Feasibility of drug screening with panels of human tumor cell lines using a microculturetetrazolium assay, Cancer Research, 48(3),pp. 589-601, 1988 